\title{
Inkade ja asteekide riikliku ning ühiskondliku korralduse võrdlusjooni ${ }^{1}$
}

Teesid: Peruu inkade riigi poliitiline korraldus kujutas endast aastatel 14381532 kõrge tsentraliseeritusastme ja tugeva keskvõimuga impeeriumi. See oli kogukondlikke joontega varajane klassiühiskond, kus riigivõimu sekkumine ühiskonnaellu oli tugev, külakogukond oli rakendatud riigivõimu teenistusse, horisontaalne mobiilsus oli kontrolli all ja vertikaalne mobiilsus olematu. Seega oli tegemist nn varatotalitaarse riigiga.

Mehhiko asteekide riigi poliitiline korraldus kujutas endast aastatel 14271519 nõrgalt tsentraliseeritud keskvõimuga konföderatsiooni, mille puhul kolmikliidu tuumikala kasutas alistatud territooriume majandusliku tagamaana. See oli tugevate kogukondlike joontega varajane klassiühiskond, kus riigivõimu sekkumine ühiskonnaellu oli väike, leidus vähe võimalusi horisontaalseks mobiilsuseks, kuid oli täiesti võimalik vertikaalne mobiilsus. Seega oli tegemist riigiga, kus oli säilinud rohkesti sõjalise demokraatia tunnuseid.

Märksõnad: asteegid, impeerium, inkad, konföderatsioon, Mehhiko, Peruu, sõjaline demokraatia, varatotalitaarne riik

\section{Sissejuhatus}

Käesolevas artiklis võetakse vaatluse alla Peruu inkade riigi ja Mehhiko asteekide riigi poliitiline korraldus ning ühiskonna struktuur nende riikide viimasel, ekspansionistlikul perioodil. Inkade ja asteekide materjal on esitatud mõnevõrra erinevalt. See on tingitud nende poliitilise ajaloo erinevusest. Kui inkade riigi puhul on nii kujunemisjärgus kui ka hilisperioodil tegemist ühe ja sama laieneva riikliku struktuuriga ketšua hõimuliidu ülemkihi - inkade juhtimisel, siis asteekide puhul leidis riiklikus struktuuris aset oluline muutus - iseseisvad asteekide linnriigid sõlmisid kolmikliidu, mis asus teostama ekspansioonipoliitikat. Sotsiaalset stratigraafiat ja riigi ekspansiooni kulgemise iseärasusi kirjeldatakse allpool sarnaselt. Järeldused esitatakse mater-

http://haldjas.folklore.ee/tagused/nr33/kulmar.pdf 
jali võrdluse põhjal. Autor toetub tähtsamatele konkista-perioodi kroonikatele ja mitmete oluliste uurijate teostele. ${ }^{2}$

\section{Inkade riigi ekspansionistliku perioodi (1438-1532) poliitiline ja ühiskondlik organisatsioon}

\subsection{Riigi territoriaalne struktuur ja valitsemissüsteem}

Inkade riigi territoriaalse struktuuri ja valitsemissüsteemi kohta leiab täpsemaid andmeid nt Father Bernabé Cobo koostatud inkade impeeriumi ajaloost (Cobo 1996: 189-202). Tahuantinsuyu (Nelja Ilmakaare riik) oli jaotatud neljaks suurprovintsiks (suyu), mille piiride lõikepunktis paiknes pealinn Cuzco: Chinchaysuyu (Peruu loodeosa kuni Ecuadorini), Antisuyu (kirdeosa, põhiliselt Andide idanõlv ja vihmametsade madalmaa), Collasuyu (kagupoolne kõrgmaa, Titicaca järv, Boliivia, Argentina loodeosa ja Tšiili põhjaosa) ning Cuntisuyu (Peruu lõuna- ja lääneosa kuni Vaikse ookeani rannikuni). Suurprovintsid koosnesid omakorda väiksematest piirkondadest.

Riigi tipus oli ainuvalitseja - Sapa Inca (keiser), keda austati päikesejumala pojana. Tema järeltulijaks võis saada see peanaisega sigitatud poegadest, keda peeti trooni vääriliseks. Täisealisena anti troonipärijale võimalus tõestada end kaasvalitsejana. Kuigi keisril oli piiramatu võim, sõltus tema valitsemise edukus ülemkihi erinevate huvide rahuldamisest. Eriti tähtsal kohal olid siin sõjapealikute huvid. Keisrit abistas valitsemisel riiginõukogu, kuhu kuulusid troonipärija, mõned lähisugulastest kõrgametnikud, vägede ülemjuhataja ja päikesejumala ülempreester. Tegelik võimustruktuur oli rangelt hierarhiline ja läbipaistmatu (Murra 1958).

Vastavalt inkade muistse hõimuühiskonna etnilisele ja sotsiaalsele dualismile määrati provintside valitsevatesse ametisse kaks paralleelset valitsejat, kes olid teineteisele abiks ja jälgisid teineteist. Analoogne võimujaotus valitses ilmselt ka muudes ametkondades. Keisri nõunikeks olid nelja suurprovintsi asehaldurid ja kõrgaadlikest provintsikubernerid, kes asetusid valitsushierarhiasse vastavalt oma provintside suurusele, st maksukohuslastest perede arvule, kes olid jagatud kümmekondadesse (Wedin 1965: 34-46). Mitteaadlikud tohtisid täita vaid kõige madalamaid haldusülesandeid.

Ametnikehierarhia paistis välja nähtavate võimusümbolite - käitumise ja rõivastuse - kaudu. Alistatud rahvaste lojaalsed juhid jäeti troonile, kuid nad valitsesid pigem näiliselt ja andsid oma tegevusest aru inkadest keskvõimu esindajatele. Nad pidid oma lapsed õiges vaimus kasvatamiseks ja koolitamiseks pealinna pantvangideks saatma (Cunow 1937: 58-81). 


\subsection{Võimuvahendid: statistika ja kommunikatsioonisüsteem}

Põhjalikuma ülevaate inkade riigi võimuvahenditest saab näiteks Pedro Cieza de Leóni La Crónica del Perú [1553] LIX, LX, XCII, XCIII ja CV peatükist (Cieza de León 1988). Impeeriumi rahvastiku ja materiaalsete ressursside haldamiseks, sealhulgas andamite üle arvepidamiseks õpetati välja erilised ametnikud (quipucamayoc). Nad töötasid nn sõlmkirjaga (quipu), mis oli üles ehitatud detsimaalsüsteemis ja kus informatsiooni kandjaks oli peanöörile kinnitatud abinööride arv ja värv ning neisse tehtud sõlmede kuju ja arv. Teadaolevalt ei olnud quipu mõeldud ulatuslike sõnaliste tekstide ülestähendamiseks. Maksukohuslastest ülevaate saamiseks oli riigi elanikkond jagatud perede kaupa kümmekondadeks ja sealt edasi kümnendsüsteemis suuremateks üksusteks.

Riigi tähtsamad punktid olid ühendatud tiheda teedevõrguga. Kaks paralleelset peateed kulgesid all rannikuribal ja ülal Andides Tšiilist Ecuadorini. Need olid ühenduses rohkete haruteedega. Kuna inkad ei kasutanud ratasveokeid ega ratsaloomi, oli sidepidamine korraldatud tihedalt asetsevate postijaamade ( andmise põhimõttel. Sidet peeti ka suitsu- ja valgussignaalide abil (Espinoza 1990: 345-398).

\subsection{Sotsiaalsed kategooriad ${ }^{3}$}

2.3.1. Aadelkond koosnes kolmest kihist. Kõrgeimal astmel olid inkad ise ehk ketšua-indiaanlaste põlisaristokraatia, kes oli piisavalt arvukas, et hoida riiki oma kontrolli all. Järgmisel astmel olid segaverelised inkad panacad, aga ka Cuzco ümbruskonna etniliste rühmade eliit ehk nn inkad eesõiguse poolest. Nimelt oli impeeriumi südames oluliselt muutunud külakogukonna algne tähendus. Cuzcos ja selle ümbruses oli muistne külakogukond ayllu muutunud panacaks. Panacasse kui nn eesõigustega ayllusse kuulusid mitmete keisrite tuhanded järglased, sisuliselt aadlipäritoluga inimesed, kelle seast värvati riigiametnikke ja muid ametikandjaid. Kolmandal astmel oli inkade suhtes lojaalne alistatud rahvaste ülemkiht, kellel oli privileege ja kellele oli kohalikes asjades jäetud teatud otsustusõigus.

2.3.2. Suurem osa rahvastikust, kes külades põldu harisid, karja kasvatasid või käsitööd tegid, olid töötegijad - hatunruna. Inkade riigi elanikkonna sotsiaalse organisatsiooni jaotuse aluseks oli ayllu ehk külakogukond. Aylludest koosnesid piirkonnad ja provintsid. Lihtrahva eraldatus aristokraatiast oli range ja kogukondlaste vertikaalne mobiilsus kõrgematesse ühiskonnakihti- 
desse ei olnud reeglina võimalik. Ka horisontaalne mobiilsus, st elukutse valik ühiskonna sees allus võimude rangele valikule ja kontrollile.

Põllumaa ja kariloomad olid inkade riigi kõige suuremate materiaalsete väärtuste allikas. Riik, st keiser oli kõrgeim maaomanik. Riigivõim reguleeris kõlvikute ümberjagamist ja kasutamist. Suurem osa põllumaast oli ayllude kasutuses ja see jagati kolme ossa. Üks osa sellest jagati perioodiliselt ümber vastavalt külakogukondade suurusele ja seda moodustavate taluperede liikmete hulgale. Sealt saadav toodang jäi maaharija pere elatiseks. Ülejäänud kahte osa põllumaast haris külakogukond kollektiivselt. Selle toodang võ̃orandati ja oli mõeldud riigiaparaadi, õukonna, ametnikkonna, sõjaväe, preesterkonna, käsitööliste (camayoc), ent ka kogukonna mittetöövõimeliste liikmete - vanurite ja invaliidide - ülalpidamiseks. Cuzcos ja selle lähikonnas elava põlisaristokraatia ja panaca-aadli ülalpidamiseks mõeldud maad harisid sinna ümber asustatud sõltlased yanacunad. Kuna panacade hulk pidevalt kasvas, pidi iga keiser hõivama nende ülalpidamiseks uusi maa-alasid. Keiser jagas elatise andmiseks maid ka oma ustavatele ametnikele. Pidev haritava maa puudus oli seega ekspansioonipoliitika üheks mootoriks.

Lisaks naturaalandamile, mida maaharijatest, loomakasvatajatest ja käsitöölistest kogukonnad oma toodangust pidid tasuma, tuli aylludel täita ka sunniviisilist tööteenistust (mita) - ehitada teid, sildu, kindlusi ja niisutussüsteeme, võtta osa sõjakäikudest sõjameeste või abitööjõuna, samuti teenida kullerite ja kaubavedajatena. Selleks rakendati töökõlbulikke abielus täiskasvanuid. Nende äraolekul tegi ülejäänud ayllu nende igapäevase töö. Alates keiser Pachacutec Yupanquist, st 15. sajandi keskpaigast, oli tekkinud veel kolm ühiskonnakihti, kelle seisund oli päritav ja kes sõltusid vahetult riigist: yanacuna, acllad ja mitmacid.

\subsubsection{Yanacuna moodustasid väga erinevatesse kategooriatesse kuu-} luvad sõltlased, keda varem on ekslikult peetud ka orjadeks. Yanad töötasid eranditult mita-töö korras kas riiklikel või keiserlikel objektidel ja põlisaristokraatia maavaldustes, samuti pealinna ümbruses panacade maadel. Yanade päritolu on ebaselge, kuid on võimalik, et see seisus tekkis selliste ayllude baasil, keda oli karistuseks hatunruna õigustest ilma jäetud. Yana staatus oli päritav ja muutumatu.

2.3.4. Acllad olid ilusad noored naised, keda riigivõimu esindajad aylludest välja valisid ja kes saadeti elama riigi tähtsamates keskustes asuvatesse internaatidesse. Abiellumine ja laste saamine oli neil keelatud. Nad tegid käsitööd ülikkonna vajadusteks, olid teenistuses templite juures või said keisriperekonna konkubiinideks. Acllasid toodi mõnikord ka jumalatele inimohvriks. Inkad ohverdasid muide inimesi ainult eriti tähtsatel puhkudel, sest inimres- 
surssi suhtuti eelkõige kui tööjõudu. Acllade kui väljavalitute staatus oli ühekordne ja piiratud nende eluajaga.

2.3.5. Mitmaci ühiskonnakihi moodustasid hõimud, keda asustati ayllude kaupa ümber (1) võimu kindlustamiseks uutesse alistatud piirkondadesse, (2) alistatud piirkondadest mässude ennetamiseks riigi vanadesse piirkondadesse või (3) uudismaade harimiseks ühest piirkonnast teise. Mitmacidena asustati pealinna ümber ka arvukalt käsitöölisi. Mitmacide staatus oli päritav ja muutumatu (Oberem 1990; Rostworowski de Díez Canseco 1988: 181-234).

\subsection{Ekspansioonipoliitika ja sõjavägi}

Inkade riigi vallutuspoliitikast ja sõjaväest saab ülevaate mitmetest trükiallikatest (vt nt Ayala 1980: 122-151; Garcilaso de la Vega 1988: III rmt 4 ptk \& V rmt 12. ptk). Inkad kehtestasid oma ülevõimu vallutatud aladel väga kiiresti. Sealjuures rakendati mitte ainult sõjalisi, vaid ka nn rahulikke abinõusid. Mitmetel juhtudel kasutati ära piirkondade väikepealike omavahelisi pingelisi suhteid või nende äraostmist kingituste ja soodustuste tegemise abil. Piirialade riigiga lõplik liitmine viidi lõpule kindluste ehitamise ja garnisonidega mehitamise teel. Vallutatud või survet avaldava diplomaatia abil hõivatud territooriumid integreeriti tihedalt riigi koosseisu. Suurt rõhku pandi lojaalsuse kasvatamisele keskvõimu vastu: maksukoormuse suurus oli reguleeritud, elementaarne eluks vajalik rahvale tagatud, tarbetut vägivalda ei rakendatud, uued etnilised rühmad tohtisid kummardada oma endisi jumalaid, rohked usupühad võimaldasid lõbustusi ning meelsuse kujundamise eest hoolitses vastav ideoloogiateenistus. Seetõttu ei läinud Peruu hõimud üle hispaania vallutajate poolele ja avaldasid pikka aega vastupanu.

Inkadel oli suur alaline armee. Alaliseks sõjaväeteenistuseks hoiti kutseliste sõduritena relvade all mõningaid sõjakaid etnilisi rühmi, näiteks cañariindiaanlasi, kes asustati ümber Cuzco lähistele ja olid muudest kohustustest vabastatud. Erinevate etniliste rühmade sõjamehed võitlesid inkade armees omaenda üksuste, relvade, rõivastuse ja juhtidega. Sõjakäikudele värvati tugevaid terveid mehi ka mita korras. Kahest või kolmest üksusest koosnevad väeosad olid inkadest ohvitseride kõrgema juhtimise all. Iga teine ohvitseriamet põhines dualistlikul printsiibil - üks asendas või ka jälgis vajadusel teist. Sõjaväkke võeti ka naisi, kes täitsid abiteenistuskohustusi. Inkade riigi väeüksused olid mobiilsed ja treenitud kiiresti liikuma tugevasti liigendatud maastikul. Hispaania 16. sajandi kroonikud on hinnanud 
kõrgeslt nende võitlusvõimet. Otsustava Cajamarca lahingu suutsid hispaanlased võita ainult tänu ootamatusele ja sõjakavalusele (Busto Duthurburu 1981: 209-233).

\section{Mehhiko poliitiline ja ühiskondlik organisatsioon 15. sajandil ja 16. sajandi algul}

\subsection{Asteekide ühiskonna poliitiline põhistruktuur}

Asteekide ühiskonna poliitilise struktuuri kohta leiab põhjalikumaid andmeid mitmetest kirjalikest allikatest (nt Sahagún 1990: VIII rmt; Durán 1967). KeskMehhiko poliitilised põhiüksused olid piiratud territooriumiga riiklikud moodustised, mis sarnanesid linnriikidele. Igaühes neist oli linnakeskus palee ja templiga, kõrgkihi elamud ja riigiasutuste hooned. Linna ümbritses majanduslik tagamaa külade ja majanditega. Linnriigid olid tihedalt asustatud. Tihti moodustasid nad omavahel vallutus- või kaitse-eesmärgiga konföderatiivseid liite. Linnriike valitsesid perekonnad - dünastiad. Rahvastik kuulus enamasti nahuatli keelt kõnelevatesse etnilistesse rühmitustesse, kellel olid sarnased religioossed uskumused ja riitused, eriti inimohvritoomine jumalate toitmiseks maailma edasikestmise nimel. Linnriikidevahelise suhtlemise käitumiskoodeksisse kuulus vaba läbipääsu lubamine kõikide linnriikide poolt austatavate jumaluste pühamutesse, üldistesse kauplemiskohtadesse, saadikupuutumatus ja korrakohane sõjakuulutamine. Alalist sõjaväge ei olnud. Mehed said noorukina sõjalise väljaõppe ja kutsuti relvile vastavalt vajadusele (Vaillant 1949: 75-85; Davies 1989: 115-159).

\subsection{Asteekide ühiskonna sotsiaalne struktuur}

Asteekide ühiskonna sotsiaalse struktuuri kohta leiab põhjalikumat teavet eelosundatud allikatest (Sahagún 1990: IX rmt; Durán 1967). Elanikkond jagunes kahte sotsiaalsesse põhiklassi. Ülemkiht oli põhiliselt sünnipärane aadel (pilli), mis hõlmas ligikaudu 10\% rahvastikust. Aadlike ja lihtrahva vahel oli võimalik sõjalisest vaprusest tingitud vertikaalne sotsiaalne mobiilsus, mis võimaldas ka mitteaadlikel saada auastmeid, riigiameteid, maksuvabastusi ja maavaldusi. Sel kombel kujunesid välja arvukas mittepärilik teenistusaadel ja madalam preesterkond.

3.2.1. Pärusaadel koosnes arvukatest päritolu, omandi ja võimu poolest erinevatest suguvõsadest. Suguvõsapead kandsid ajaloolisi tiitleid, mille juurde kuulus sõna “isand" (teuctli). Aadlisuguvõsa pea valiti enamasti mees- 


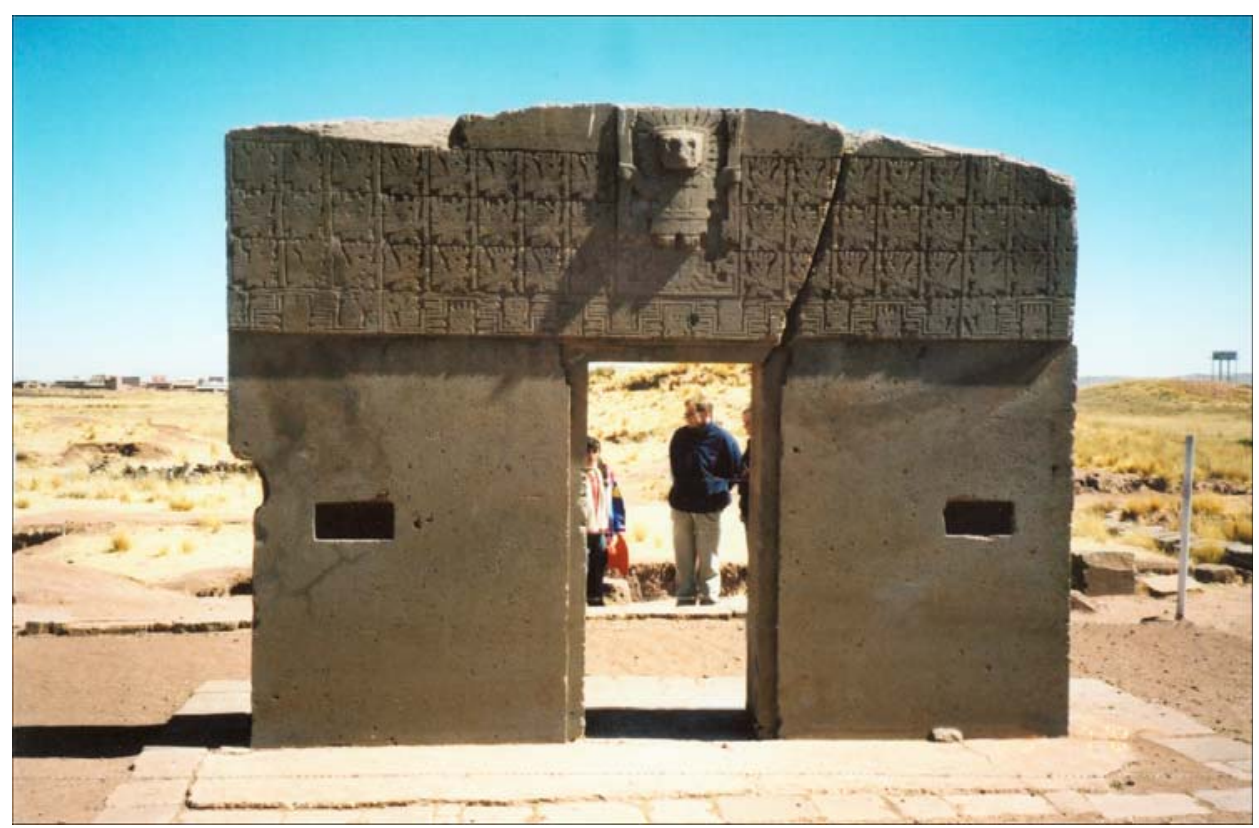

Foto 1. Tiahuanaco Päikesevärav (I at pKr) - mõistatuslikumaid megaliitmuistiseid. Erakogu.

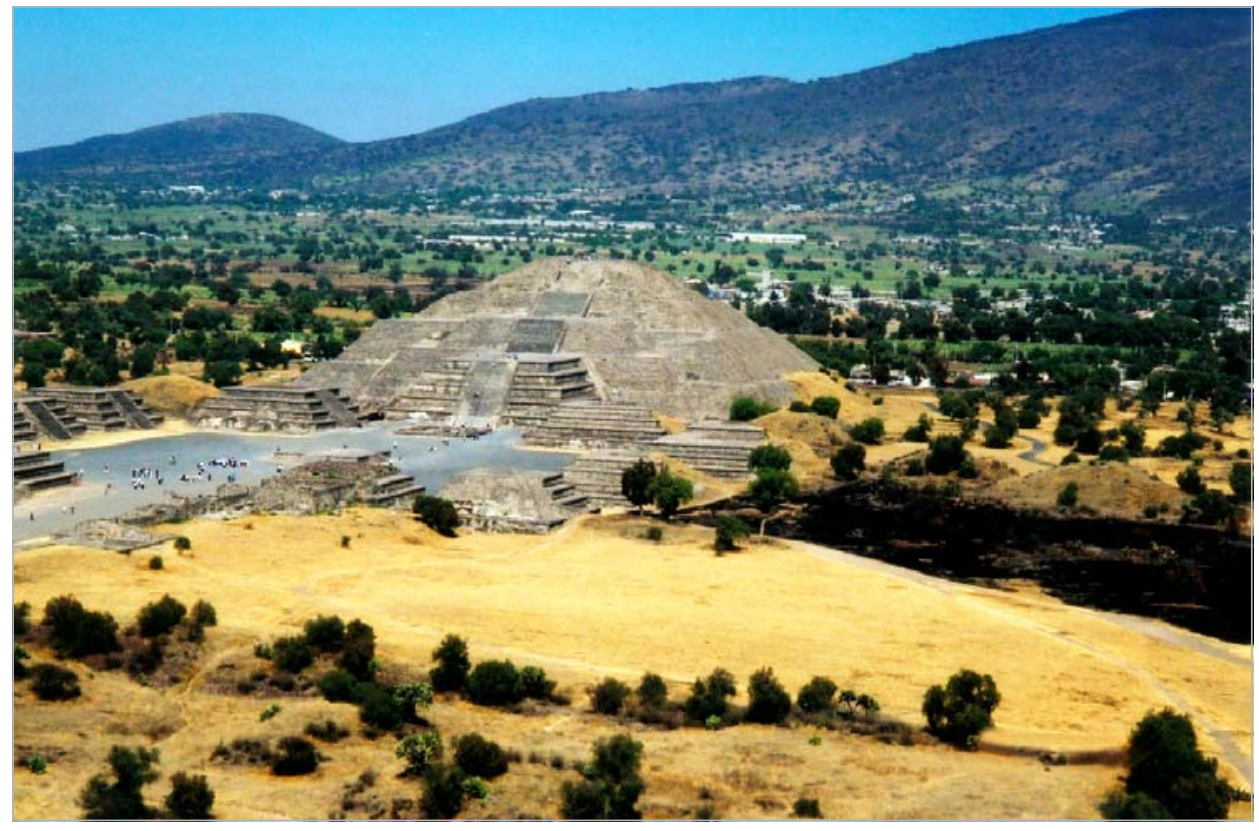

Foto 2. Teotihuacan. Vaade Päikesepüramiidi tipust Kuupüramiidile. Erakogu. 


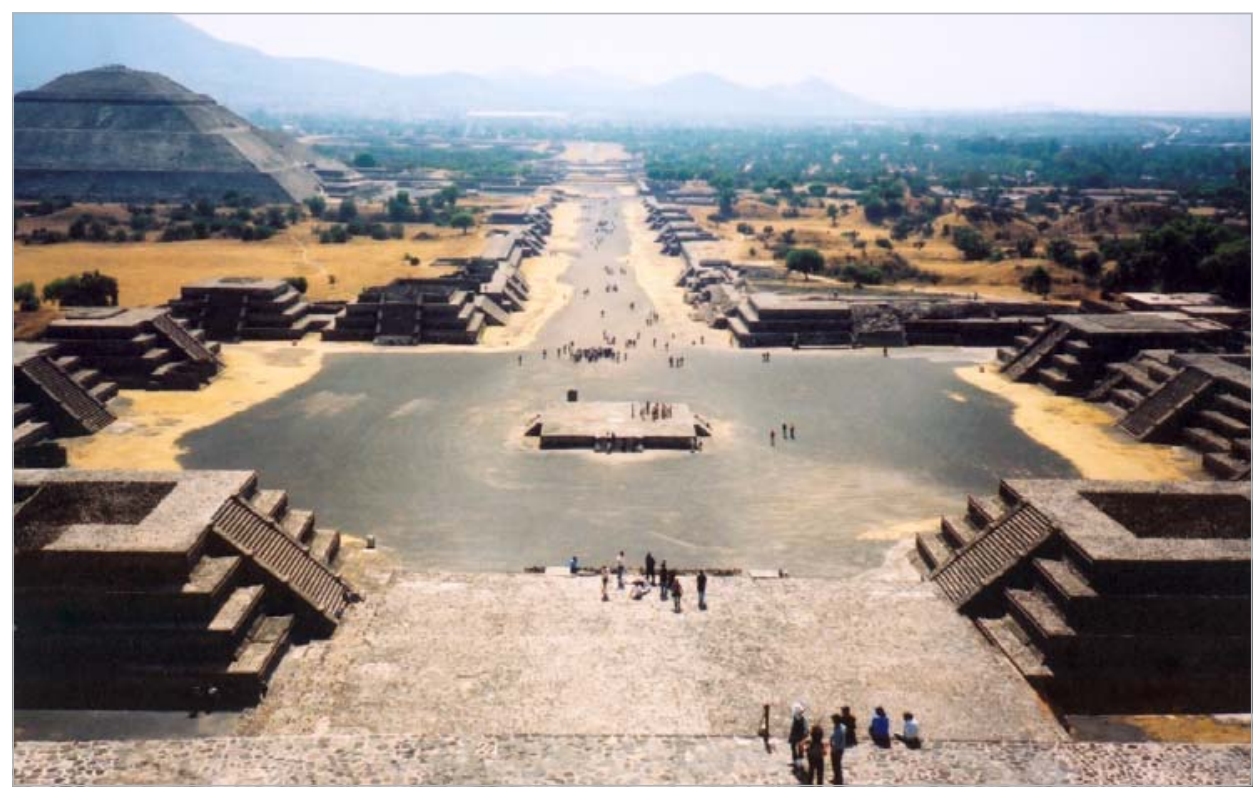

Foto 3. Teotihuacan. Vaade Kuupüramiidilt Surnute teele. Erakogu.

liinis, kusjuures arvestati sõjalisi teeneid ja ametikohta riigis. Võimatu ei olnud ka emajärgne pärilusliin. Valijateks olid kas seisusekaaslased või riigivalitseja. Aadlisuguvõsa ja selle peamehe residents oli nn isandamaja (teccalli), mille juurde kuulus maavaldus koos vasallide ja suguvõsa kõrvalliinidesse kuuluvate lähikondlastega. Aadli maavaldused (pillalli) olid päritavad, sageli ka naisliinis. Teuctlid ehk maaomanikud võisid pidada mitut naist ja neil võis olla suuri rikkusi, paljud alamaadlikud olid aga vaesed ega erinenud kuigivõrd talupoegadest. Teuctlid olid maksudest vabastatud. Iga suurem aadlisuguvõsa kujutas endast suurel määral sõltumatut majandusüksust, mille peamehel oli sageli suur poliitiline ja juriidiline võim. Aadliku võimu ulatuse määras tegelikult ära tema vasallide hulk.

\subsubsection{Igal linnriigil (tlatocayotl) oli üks või ka rohkem juhtivatesse aadlisuguvõsadesse kuuluvat valitsejat (tlatoani - kõneleja). Tlatoani legitiimsuse määrasid nende esivanemate teened riigi asutamisel ja abielude kaudu põlvnemine varasema tolteegi tsivilisatsiooni valitsejasoo naistest. Troo- nipärimiskord tulenes võimul oleva aadlisuguvõsa pärimiskorrast. Valitseja täitis riigi kõrgeimaid religioosseid, administratiivseid ja kohtunikuülesan- deid. Sünniaadli seast pärinesid ka kohtunikud, kõrgemad ja keskastme amet- nikud ning kõrgem preestritehierarhia.}


3.2.3. Mitteaadlikud (macehualtin - töötajad), kes moodustasid suurema osa rahvastikust, tegelesid põlluharimise või käsitööndusega, kusjuures enamasti jätkasid pojad isade tegevusala. Üks osa lihtrahvast elas sõltlastena aadlimajandites, teine osa nõrgalt kihistunud suguluse ja tegevusala alusel moodustunud kastilaadsetes korporatiivsetes rühmades (calpulli - suurmaja) mitmel pool riigi territooriumil, töötades kollektiivselt templite, noormeeste kasvatusmajade ja riigiasutuste maadel ning makstes andamit. Sellisel suguvõsal oli ühine maavaldus, millest iga pere sai maatüki enda elatamiseks. Macehualtinite teine kohustus oli sõdimine. Sõjas üles näidatud vapruse eest võis lihtinimene saada autasu ja pääseda ladvikusse. Töötajatest madalamal oli rühm vabu inimesi, keda mingil põhjusel põlati - neil polnud õigust maale ja nad töötasid sulastena oma hõimlaste juures.

3.2.4. Mehhiko linnriikides oli ka kahte liiki orje: ühed olid orjadeks muudetud sooritatud kuriteo eest, teised müüsid end ise vaesuse tõttu orjadeks. Orjusest võis vabaneda kas enda vabaks ostmisega või juhul, kui orja omaniku lesk otsustas orjaga abielluda. Sõjavange orjadena tavaliselt ei peetud-nad surmati ohvrialtaril.

3.2.5. Kinnise kasti moodustasid kaupmehed (pochteca). Nad elasid omaette linnaosas, abiellusid ainult omavahel ja ainult nende lapsed tohtisid hakata pochtecadeks. Kaupmeestel oli vaba liikumise õigus, mistõttu riigivõimud kasutasid neid luurajate ja sõnumiviijatena. Omaette kutsekorporatsioonidesse või kastidesse kuulusid veel kvalifitseeritud käsitöölised ja transporditöölised (tlamama - kandjad).

3.2.6. Noorukeid õpetati kahte tüüpi koolides. Tähtsamate templite juures asusid calmecacid, kus aadlinoormehed said õpetust sõjanduses, religiooni tundmises, valitsemiskunstis ja kaunites kunstides. Lihtrahva seast pärit noorukid õppisid telpochcallides eelkõige hästi sõdima, aga ka paljusid praktilisi tööoskusi (Hinz 1990; Prem 1999: 34-53; vt ka León-Portilla 1959: V ptk).

\subsection{Asteekide riigi struktuur ja poliitika ekspansiivsel perioodil}

Asteekide riigi struktuuri ja poliitika kohta ekspansiivsel perioodil leidub üksjagu kirjandust (vt nt Sahagún 1990: XII rmt; Acosta 1991: 173 jj; Durán 1967).

3.3.1. Kolmikliit. Asteekide kolmikliidul, mis loodi Tenochtitlani valitseja Itzcoatli juhtimisel 1430. aastatel Tenochtitlani, Acolhuacani (pealinnaga Tet- 
zcoco) ja Tlacopani riikidest, ei olnud algul poliitilist liidrit. Valitseja määrati liidule läbirääkimiste käigus. Vastavalt kõigi kolme pealinna geograafilisele asendile oli igal osapoolel oma piirkonnas poliitiliste ettevõtmiste vabadus. Sisepoliitiliselt oli igaüks neist kolmest riigist iseseisev, millel olid omad, teistest lepinguosalistest sõltumatud valitsemisstruktuurid. Välispoliitika ja sõjakäigud kooskõlastati omavahel. Põhijoontes oli igal kolmliidu riigil sisemine õigus määrata oma surnud valitsejale järglane. Vajalik oli vaid see, et mõlemad teised valitsejad seda otsust pidulikult tunnustaksid.

Tenochtitlan muutus ajapikku kolmikliidu juhtivaks linnaks. Liitriiki juhtis ametlikult seal resideeriv suur riiginõukogu, kuhu kuulusid kõikide liitriigi linnade esindajad. Otsustav hääl kuulus aga kolmikliidu rajanud linnriikide valitsejatele: Tetzcoco tlatoanile allus seadusandlus ja ühiskondlike ehituste püstitamine, Tlacopani tlatoani vastutas majanduse ja käsitöö eest ning Tenochtitlani tlatoani võttis enda peale välispoliitika ja sõjavägede juhatamise, mistõttu ta kandis ka ülemvalitseja tiitlit tlacatecuhtli. Formaalselt valisid tlacatecuhtli kahekümne tähtsama asteegi aadlisuguvõsa esindajad, kuigi ametikoht oli tegelikult päritav. Tlacatecuhtli valis endale järglase juba eluajal, erinevalt Tetzcocost, kus uueks tlatoaniks võis saada ainult valitseja peanaisest sündinud poeg. Tlacatecuhtli kõrval valitses riigi siseasjade üle ja peakohtunikuna asevalitseja - cihuacoatl. Tlacatecuhtli juhatas väikest riiginõukogu, kuhu kuulus peale cihuacoatli veel neli liiget, nende seas Tenochtitlani peajumala Huitzilopochtli ülempreester (Carrasco \& Monjarás-Ruiz 1998; Zantwijk 1990).

3.3.2. Ekspansioonipoliitika ja sõjavägi. Umbes saja aasta jooksul (14271519) alistasid asteegid oma võimu alla peaaegu kogu Mehhiko, kokku 38 riiki või linnriiki. Ent tegelik asteekide riik piirdus vaid kolmikliidu territooriumiga - Tenochtitlani ja tema kahe liitlaslinnaga. Teisi alistatud piirkondi peeti ainult territooriumideks, mis pidid rohket andamit maksma. Need territooriumid olid siseasjades iseseisvad, seal olid troonil kohalikud valitsejad, kuid olukorda jälgisid ka asteekidest kubernerid, kes kandsid kohapeale majutatud kolmikliidu sõjaväegarnisonide abil hoolt selle eest, et maksud laekuksid tähtaegselt. Andamite sissenõudmiseks oli kolmikliidul hiiglasuur ametnikkond, mille esindused paiknesid allutatud territooriumide pealinnades. Andami hulka kuulus ka teatud arv inimesi, keda kas nõuti orjadeks või saadeti Tenochtitlani ohverdamiseks.

Sõjaretkede põhieesmärk ei olnud lisaks territooriumi alistamisele mitte vaenlaste tapmine, vaid võimalikult suure hulga sõjameeste vangistamine. Sõjavangid ohverdati kolmikliidu pealinnade templite ohvrialtaritel. Juhul, kui asteegi kolmikliidul ei olnud parajasti kellegagi sõdida, korraldati mõne alistatud terri- 
tooriumiga nn lillesõda. See oli sõjamäng, mis meenutas pärissõda alates sõjakuulutamisreeglitest kuni asteekide võiduni, mis lõppes vangide võtmisega. 16. sajandi kroonikad ja ka arheoloogilised leiud annavad tunnistust kümnetest tuhandetest inimohvritest. Linnad, kes mässu tõstsid ja kolmikliidule vastu hakkasid, hävitati. Viha asteekidest okupantide vastu oli nii suur, et 1519. aastal saabunud Hispaania vallutajad leidsid ülestõusnud linnade seas endale hulgaliselt liitlasi, mis oli asteekide vapra sõjaväe lüüasaamise olulisimaid põhjusi (Vaillant 1949: 151-158).

\section{Võrdlusjooned}

\subsection{Riigivõimu ulatus}

Inkade riik oli tugeva keskvõimuga ka enne ekspansiooniperioodi. Keskvõim kontrollis Tahuantinsuyu territooriumi kõiki provintse kõikides olulistes tegevusvaldkondades.

Asteekide linnriigid koosnesid linnalisest võimutsentrumist ja majanduslikust tagamaast. Ka ekspansiooniperioodil oli tuumikriik vaid Tenochtitlani juhitud kolmikliit ja alistatud territooriumide üle kindlustati eelkõige majanduslik võim.

\subsection{Valitsemisviis, valitseja võimu ulatus ning võimujärglus}

Inkade riik oli impeerium, mida valitses piiramatu võimuga keiser, kelle trooni päris tema tahtel tema ja ta peanaise võimekaim poeg.

Asteekide riik oli konföderatsioon, mille ülemvalitseja, kes oli n-ö esimene võrdsete seas, valis formaalselt sugukondlik esindusorgan, kuid sisuliselt päris trooni üks eelmise valitseja poegadest.

\subsection{Valitsemisorganid}

Inkade keisrit abistas valitsemisel väikesearvuline riiginõukogu, kuhu kuulusid troonipärija, vägede juhataja ja ülempreester. Täidesaatva võimu rollis olid mitmesuguste ametkondade juhid ja kubernerid, kelle määras keiser. Suurde riiginõukogusse kui nõuandvasse kogusse määras keiser kõrgaadlikest suurprovintside asevalitsejad ja sõjaväepealikud. Sugukondlikud esindusorganid olid kaotanud oma tähtsuse ja lakanud olemast.

Asteekide ülemvalitsejat abistas valitsemisel kuueliikmeline riiginõukogu, kuhu kuulus ka suure võimuulatusega asevalitseja. Ülemvalitseja oli osa ülesandeid delegeerinud teistele kolmikliidu valitsejatele. Nõuandvaks 
organiks oli suur riiginõukogu, kuhu kuulusid kõikide tuumikriigi linnade juhid. Suur võim oli ka sugukonnapealikute kogul, kes võis formaalselt valida ja ka tagandada ülemvalitsejat.

\subsection{Maksustamine}

Inkad jaotasid kogukonna toodangu kolme ossa: üks osa jäi vahetule tootjale, teine sai keisrile või maaomanikule ning kolmas kogukonna töövõimetute liikmete, preestrite, sõdurite, käsitööliste ja tööteenistusse saadetute ülalpidamiseks, mis sisuliselt teenis samuti riigi huve. Lisaks tuli regulaarselt täita sunduslikku tööteenistust. Kutselised sõjamehed ja piirialadele ümberasustatud olid maksudest vabastatud. Andami suuruse ja maksustatavate üle peeti ranget arvestust. Võimud jälgisid, et tootjale jääks alles vähemalt elatusmiinimum.

Asteegi kogukondlased pidid võõrandama toodangu maaomanikule, kes pidas sellest ülal ennast ja oma töötegijaid, tasus riigiandami ja müüs osa kaupmeestele. Maaomanikuks võis olla nii aadlisuguvõsa kui ka töötav kogukond. Maaomanik pidi sõja korral välja panema ja varustama teatud hulga sõjamehi. Avalikele töödele saadeti orje või madalaima staatusega vabu kogukondlasi. Alistatud territooriumidelt nõuti üle jõu käivat andamikoormust, mis tekitas sotsiaalseid rahutusi.

\section{5. Ühiskonnakihid}

Inkade klassiühiskond koosnes aadlist ja lihtrahvast. Pärusaadli kõrvale oli tekkinud arvukas uusaadel (keisrite segaverelised lapsed) ja privileegiaadel (inkadele lojaalsed hõimupealikud). Lihtrahva seast kasvas välja kolm spetsialiseeritud tegevuslaadiga ühiskonnakihti: ümberasustatud pered, väljavalitud naised ja aadli isikliku maaomandi harijad. Orje inkade ühiskonnas ei olnud.

Asteekide klassiühiskond koosnes aadlist, vabast lihtrahvast ja orjadest. Pärusaadli kõrvale oli tekkinud sõjaliste teenetega teenistusaadel. Lihtrahva seas tekkis mitmeid sotsiaalseid rühmi, kes erinesid omandisuhete ja maksukohustuse määra poolest. Osa töötajaid jagunes elukutsete kaupa kinnistesse kastidesse. Vaeseimad kogukonnaliikmed võisid sattuda ka orjusesse. Sõjavangid ohverdati jumalatele.

\subsection{Horisontaalne ja vertikaalne mobiilsus}

Inkade ühiskonnas oli horisontaalne mobiilsus (elukutse vaba valik) rangelt planeeritud ja kontrollitud ning vertikaalne mobiilsus (tõusmine kõrgemasse ühiskonnakihti) väga erandlik nähtus. 
Asteekide ühiskonnas oli elukutsete kastisüsteemi tõttu horisontaalne mobiilsus haruldane, ent vertikaalne mobiilsus sõjalise vapruse tasuna märksa sagedasem.

\subsection{Sõjavägi}

Inkadel oli alaline sõjavägi, mis koosnes kutselistest sõduritest ja töökohustuse korras sõjaväeteenistusse kutsututest. Sõjaväge pidas üleval riik. Abitööjõuks kutsuti kogukondlasi töökohustuse korras.

Asteekidel ei olnud alalist sõjaväge. See kutsuti kokku vastavalt vajadusele ja kõik noorukid said sõjalise väljaõppe. Vastava arvu sõjamehi pani välja ja varustas maaomanik. Abitööjõuks olid orjad ja madalaima staatusega kogukondlased.

\subsection{Ekspansiooniprotsessi eripära}

Inkad liitsid uusi territooriume kas sõjalisel teel või diplomaatiliste abinõudega. Uued piirialad integreeriti riigi koosseisu elanikkonna ümberrahvastamise abil.

Asteegid vallutasid uusi territooriume sõjalisel teel, kuid ei integreerinud neid riigi koosseisu.

\subsection{Võimude suhtumine alistatud piirkondadesse}

Inkad püüdsid tagada uute territooriumide elanikkonna lojaalsust mitmesuguste poliitiliste ja majanduslike abinõudega.

Asteegid suhtusid uutesse territooriumidesse kui kolmikriigi majanduslikesse tagamaadesse, maksustades elanikkonda ülemääraste andamitega.

\subsection{Hinnang}

Inkade impeerium oli tugeva keskvõimuga varatotalitaarne riik, mida valitseti hästikorraldatud riigiaparaadi abil. Riigi provintside töötavat elanikkonda käsitleti utilitaarselt kui kasulikku tööjõudu.

Asteekide konföderatsiooni tuumikriik oli tugevate sõjalise demokraatia tunnustega varajane klassiühiskond, mis käsitles alistatud alasid mitte riigi poliitilise osa, vaid majandusliku territooriumina. 


\section{Järeldused}

Peruu inkade riigi poliitiline korraldus kujutas endast vaadeldaval ajajärgul (1438-1532) kõrge tsentralisatsiooniastmega ja tugeva keskvõimuga impeeriumi. Ühiskonnakorralduselt oli tegemist kogukondlike joontega varajase klassiühiskonnaga, kus riigivõimu sekkumine ühiskonnaellu oli tugev, külakogukond rakendatud riigivõimu teenistusse, horisontaalne mobiilsus kontrolli all ja vertikaalne mobiilsus peaaegu olematu. Seega oli tegemist nn varatotalitaarse riigiga.

Mehhiko asteekide riigi poliitiline korraldus kujutas endast vaadeldaval ajajärgul (1427-1519) nõrgalt tsentraliseeritud keskvõimuga konföderatsiooni, mille puhul kolmikliidu tuumikala kasutas alistatud territooriume majandusliku tagamaana. Ühiskonnakorralduselt oli tegemist tugevate kogukondlike joontega varajase klassiühiskonnaga, kus riigivõimu sekkumine ühiskonnaellu oli väike, horisontaalse mobiilsuse võimalusi leidus napilt, kuid täiesti võimalik oli vertikaalne mobiilsus. Seega oli tegemist riigiga, kus esines rohkesti sõjalise demokraatia tunnuseid.

\section{Kommentaarid}

${ }^{1}$ Artikkel on seotud Eesti Teadusfondi grandiga nr 5374.

${ }^{2}$ Uurimisloost lähemalt vt Hanns Prem 1989: 33-52, 69-76, 137-177, 183-200.

${ }^{3}$ Inkade sotsiaalse kihistumise ja klasside kohta vt nt Inca Garcilaso de la Vega (1988) teose Comentarios Reales de los Incas [1609] IV raamatu 12.-14. peatükki ning V raamatu 1.-10. ja 13.-16. peatükki.

\section{Kirjandus}

Acosta, José de 1991. Das Gold des Kondors: Berichte aus der Neuen Welt 1590 und Atlas zur Geschichte ihrer Entdeckung = Historia Natural y moral de las Indias [1590]. Kroboth, Rudolf \& Meuerer, Peter H. (koost \& tõlk). Alte abenteuerliche Reiseberichte. Stuttgart \& Wien: Edition Erdmann in K. Thienemanns Verlag.

Ayala, Felipe Guaman Poma de 1980. El Primer Nueva Corónica y Buen Gobierno [1615]. Murra, John V. \& Adorno, Rolena (toim) \& Urioste, Jorge L. (komment). Colección América nuestra. Ciudad de México: Edición al Cuidado de Martí Soler Portada de Anhelo Hernández.

Busto Duthurburu, José Antonio del 1981. Perú incaico. Lima: Librería Studium S.A.

Carrasco, Pedro \& Monjarás-Ruiz, Jesús 1998. La estructura interna de la Triple Alianza. Arqueología Mexicana VI: 32: Poder y política en el México prehispánico, lk 42-49. 
Cieza de León, Pedro 1988. La Crónica del Perú [1553]. Lima: Promoción Editorial Inca S.A.

Cobo, Father Bernabé 1996. History of the Inca Empire: An Account of the Indians' Customs and their Origin Together with a Treatise on Inca Legends, History, and Social Institutions = Historia del Nuevo Mundo [1653]. Hamilton, Roland (tõlk \& toim) \& Howland Rowe, John (eessõna). The Texas Pan American series. Austin: University of Texas Press.

Cunow, Heinrich 1937. Geschichte und Kultur des Inkareiches: Ein Beitrag zur Kulturgeschichte Altamerikas. Amsterdam: Elsevier.

Davies, Nigel 1989. Die Azteken: Meister der Staatskunst - Schöpfer hoher Kultur. rororo 8522: rororo-Sachbuch. Reinbek bei Hamburg: Rowohlt.

Durán, Diego 1967. Historia de las Indias de Nueva España e islas de la Tierra Firme [1579-1581] 1-2. Garibay Kintana, Angel María (toim). Biblioteca Porrua 36-37. Ciudad de México: Editorial Porrúa.

Espinoza Soriano, Waldemar 1990. Los Incas: Economía, sociedad y Estado en la era del Tahuantinsuyo. Lima: Amaru Editores.

Garcilaso de la Vega, Inca 1988. Comentarios Reales de los Incas [1609] 1-2. Lima: Editorial Mercurio S.A.

Hinz, Eike 1990. Das Aztekenreich: Soziale Gliederung und institutioneller Aufbau. Köhler, Ulrich (koost \& toim). Altamerikanistik: Eine Einführung in die Hochkulturen Mittel- und Südamerikas. Ethnologische Paperbacks. Berlin: Dietrich Reimer Verlag, lk 189-206.

León-Portilla, Miguel 1959. La filosofía Náhuatl: Estudia en sus fuentes. Publicación del Instituto de Historia 52. México: Universidad Nacional Autónoma de México \& Instituto de Histórica \& Seminario de Cultura Náhuatl.

Murra, John V. 1958. On Inca political structure. Ray, Vern F. (toim). Systems of Political Control and Bureaucracy in Human Societies. Seattle: University of Washington Press, $1 \mathrm{k} 30-41$.

Oberem, Udo 1990. Das Inkareich unter politischem, sozialem und wirtschaftlichem Aspekt. Köhler, Ulrich (koost \& toim). Altamerikanistik: Eine Einführung in die Hochkulturen Mittel- und Südamerikas. Ethnologische Paperbacks. Berlin: Dietrich Reimer Verlag, lk 467-492.

Prem, Hanns 1989. Geschichte Altamerikas. Grundriss der Geschichte 23. Bleicken, Jochen \& Gall, Lothar \& Jakobs, Hermann (koost \& toim). München: R. Oldenbourg Verlag.

Prem, Hanns 1999. Die Azteken: Geschichte, Kultur, Religion. Beck'sche Reihe 2035. München: Verlag C. H. Beck.

Rostworowski de Díez Canseco, María 1988. História del Tahuantinsuyu. Historia andina / Instituto de Estudios Peruanos 13. Lima: Instituto de Estudios Peruanos.

Sahagún, Bernardino de 1990. Aus der Welt der Azteken = Historia general de las cosas de Nueva España [1558-1580] VIII \& IX \& XII. Rulfo, Juan (eessõna) \& Schultze 
Jena, Leonhard \& Seler, Eduard \& Dedenbach-Salazar-Sáenz, Sabine (tõlk). Frankfurt am Main: Insel Verlag.

Zantwijk, Rudolf A. M. van 1990. Politische Gliederung am Vorabend der Conquista. Köhler, Ulrich (koost \& toim). Altamerikanistik: Eine Einführung in die Hochkulturen Mittel- und Südamerikas. Ethnologische Paperbacks. Berlin: Dietrich Reimer Verlag, lk 179-188.

Vaillant, Georges Clapp 1949 = Вайян, Джордж Клапп. История аитеков=Aztecs of Mexico. Москва: Издательство иностранной литературы.

Wedin, Åke 1965. El sistema decimal en el imperio incáico: Estudio sobre estructura político, división territorial y población. Serie del Instituto Ibero-Americano de Gotemburgo. Madrid: Insula.

\section{Summary}

\section{About the Comparison of the State Authority and Social Organization by Incas and Aztecs}

\section{Tarmo Kulmar}

Key words: Peru, Incas, empire, early totalitarian state, Mexico, Aztecs, confederation, military democracy

During the period under consideration (1438-1532) the Inca state in Peru was politically a highly centralised empire with a strong central government. Its social structure was that of an early class society with some communal traits; government's intervention in social life was prevalent, village communities were put in the service of the government, horizontal mobility was regulated and vertical mobility was all but nonexistent. It represented a so-called early totalitarian state.

The Aztec state in Mexico during the period under consideration (1427-1519) was a confederation with weak central authority where the core of the confederation used conquered territories as a sort of economic backcountry. Their social organisation represented an early class society with strong communal traits, little interference from the government in the daily life of the community, few opportunities for horizontal mobility, but vertical mobility was quite possible. As such it was a state that had retained many features of a military democracy. 